\title{
CREB3L3 wt Allele
}

National Cancer Institute

\section{Source}

National Cancer Institute. CREB3L3 wt Allele. NCI Thesaurus. Code C95486.

Human CREB3L3 wild-type allele is located in the vicinity of 19p13.3 and is approximately $19 \mathrm{~kb}$ in length. This allele, which encodes cyclic AMP-responsive element-binding protein 3-like protein 3, is involved in the modulation of gene transcription. 